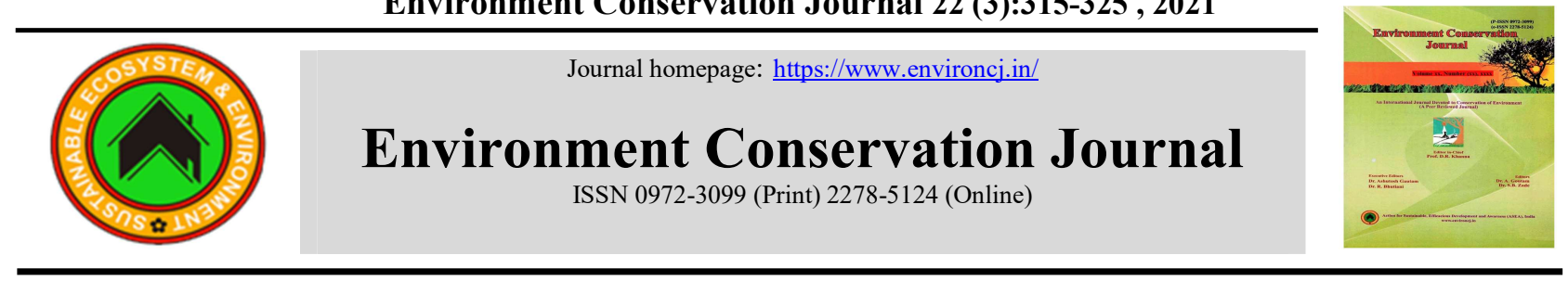

\title{
A novel soil quality assessment method for sustainable soil management and enhancing crop productivity in tribal areas of central India
}

\author{
Rajendiran, S.网
}

Division of Environmental Soil Science, ICAR-Indian Institute of Soil Science (IISS), Bhopal (Madhya Pradesh), India M.L. Dotaniya

Division of Environmental Soil Science, ICAR-IISS, Bhopal (Madhya Pradesh), India

M.Vassanda Coumar

Division of Environmental Soil Science, ICAR-IISS, Bhopal (Madhya Pradesh), India

S. Kundu

Division of Environmental Soil Science, ICAR-IISS, Bhopal (Madhya Pradesh), India

N.K. Sinha

Division of Soil Physics, ICAR-IISS, Bhopal (Madhya Pradesh), India

A.K. Tripathi

Division of Soil Biology, ICAR-IISS, Bhopal (Madhya Pradesh), India

S. Srivastava

Division of Soil Chemistry and Fertility, ICAR-IISS, Bhopal (Madhya Pradesh), India

J.K. Saha

Division of Environmental Soil Science, ICAR-IISS, Bhopal (Madhya Pradesh), India

A.K. Patra

ICAR-IISS, Bhopal (Madhya Pradesh), India

\begin{tabular}{|c|c|}
\hline ARTICLE INFO & ABSTRACT \\
\hline $\begin{array}{l}\text { Received : } 09 \text { July } 2021 \\
\text { Revised : } 08 \text { September } 2021 \\
\text { Accepted : } 24 \text { September } 2021 \\
\text { Available online: } 19 \text { December } 2021 \\
\text { Key Words: } \\
\text { Minimum Data Set (MDS) } \\
\text { Relative Yield (RY) } \\
\text { Soil Quality Assessment } \\
\text { Soil Quality Index (SQI) } \\
\text { Sustainable Soil Management } \\
\text { Tribal Area }\end{array}$ & $\begin{array}{l}\text { Soil quality degradation is a major threat to any agricultural production } \\
\text { system. Therefore periodical monitoring of soil quality status is inevitable for } \\
\text { sustainable management of agricultural production systems. Though there are } \\
\text { various methods available to assess the soil quality, simple and management } \\
\text { oriented methods are necessary. The current investigation aimed to evaluate } \\
\text { soil quality of tribal areas of central India adopting minimum dataset of } 15 \text { soil } \\
\text { physical, chemical and biological parameters. A novel scoring technique was } \\
\text { followed to score soil quality indicators based on its relation with crop yield, } \\
\text { degree of variation and percent deficiency. Relative soil quality index (RSQI) } \\
\text { was calculated and was correlated with crop productivity. Most of the soils in } \\
\text { the region had poor soil quality (77.2\% in Jhabua, 85.4\% in Alirajpur and } \\
67.2 \% \text { in Dhar) with low crop yield. The major constraints of crop production } \\
\text { in these areas were low soil organic carbon }(<0.5 \%) \text {, available } \mathrm{N}\left(<280 \mathrm{~kg} \mathrm{ha}^{-1}\right) \text {, } \\
\mathrm{S}\left(<10 \mathrm{mg} \mathrm{kg}^{-1}\right), \mathrm{P}\left(<10 \mathrm{~kg}^{-1}\right), \mathrm{Zn}\left(<0.5 \mathrm{mg} \mathrm{kg}^{-1}\right) \text {, dehydogenase activity }(10 \mu \mathrm{g} \\
\left.\mathrm{TPF} \mathrm{g}^{-1} 24 \mathrm{~h}^{-1}\right) \text { and soil depth }(<1 \mathrm{~m}) \text {. Adopting sustainable management } \\
\text { practices could improve soil quality and crop productivity. This new approach } \\
\text { is simple and systematic; this principle can be easily adoptable to other } \\
\text { locations, and principally focuses on management related and soil parameters } \\
\text { that constraint to production and ecological functions. }\end{array}$ \\
\hline
\end{tabular}

\section{Introduction}

Declining soil quality in various agrarian systems has posed a remarkable challenge to enhancing crop productivity, economic growth, and healthy environment. The major causes of soil quality degradation are inappropriate land use and soil management, desertification, erosion, salinization, 
etc. (NAAS, 2012). Existing soil management technologies in India and other developing countries have been evolved with the objective of increasing and sustaining high agricultural productivity. However the ever increasing human and animal population demands more food from the limited available land resources. To meet food demand of increasing population forces to practice intensive cultivation to achieve higher productivity. Intensive cultivation practices lead to poor resources use efficiency and other environmental consequences. For instances, partial and total factor productivity of applied fertilizers across India are decreasing (NAAS, 2006). Further imbalance use of fertilizers causes mining of nutrients from soil and emergence of secondary and micronutrient deficiencies in the soils (Shukla andBehera, 2012). Excess application of particular nutrient causes nutrient imbalance and environmental or soil quality degradation (NAAS, 2012). On the other hand, the growing concerns on food quality, groundwater quality, greenhouse gases (GHG) emissions, climate change, soil biodiversity, etc., there is a pressing need for integration and reorientation of soil management practices to improve and sustain the production systems (NAAS, 2017). Therefore it is essential to periodically monitor soil quality status of different management systems to make necessary suitable measures for sustaining or enhancing crop productivity and maintaining ecological health over a longer period.

Several methods or approaches of soil quality assessment have been adopted by different authors across the world (Andrews et al., 2004; Buenneman et al., 2018) and in India (Singh, 2007; Kundu et al., 2012; Vasu et al., 2017; Mahajan, 2020). The various approaches are visual assessments, analytical and statistical techniques (Andrews et al., 2004). Soil quality index (SQI) is largely accepted and considered the best tool for evaluation of soil quality degradation (Wang and Gong, 1998). However, there is no universally accepted dataset selection, scoring, and soil quality indexing method for different field conditions. Different soil quality indexing methods have been used by different researchers (Masto et al., 2008; Andrews et al., 2004). The widely used minimum dataset methods of soil quality indicators in previous studies are expert opinion and statisticaltools (e.g., regression, principal component analysis). The linear and non linear scoring techniques are adopted to transform the datasets into scores, but none of the previous studies have evaluated these techniques simultaneously (Masto et al., 2008; Buennemann et al., 2018). Limitations of previous studies are differences in SQI values among the various soil quality indexing methods (e.g., additive, weighted, and max-min objective functions) and differences in evaluating the methods using the same data simultaneously in a similar field conditions (Masto et al., 2008).

In spite of the above limitations, assessing SQI of different land use and soil management systems is important to locate the areas to be carefully managed for sustainable development. Previously the concept of SQI tool has been used and applied in different places following various approaches for assessing soil quality (Singh, 2007; Masto et al., 2008; Kundu et al., 2012; Vasu et al., 2017). In this study also SQI concept was adopted with a novel scoring procedure for selected minimum dataset of indicators. The objective of the current investigation is to assess the soil quality status of tribal population dominated and most backward areas of central India using minimum set of indicators with simple novel scoring procedure. Further thus obtained SQI is correlated with productivity functions. The major soil parameters that constraint soil quality and crop productivity are also identified for suitable integrated land and soil management practices to sustain the agricultural systems in the region.

\section{Material and Methods \\ Background of study area}

Tribal population dominated and economically most backward Alirajpur, Jhabua and Dhar districts of Madhya Pradesh was selected for the investigation (Figure 1). The study area is situated in the Central Plateau and Hills Agro-Climatic Region. It comes under the Madhya Bharat plateau, western Malwa Plateau, eastern Gujarat plain Vindhya Satpura range and Narmada valley AgroEcological Region. The tribal population in Alirajpur and Jhabua districts is more than $80 \%$ of the total population, and more than $60 \%$ in case of Dhar. Larger section of population (more than $50 \%$ ) in these districts lives in poverty. The major tribal groups in these districts are Bhil and Bhilala. 
They largely depend on agriculture and allied activities for their livelihood. The major crops grown in these districts are maize (both in rainy and winter seasons), soybean, cotton, and black gram in rainy season; wheat and gram in winter. Some of the minor crops are black gram, groundnut, peas, sorghum, pigeon pea, chilli, garlic, potato, onion, tomato, and paddy. The soils of these regions are grouped under Entisols and more than $80 \%$ of the soils are shallow to medium deep soils (Velayutham et al., 1999). Lands are highly drought-prone and degraded waste lands. Major agricultural and socio-economic related constraints are failure of rainfall and low water availability, severe land degradation and soil erosion, undulating topography, shallow soils, low soil water retention capacity, low crop productivity, mono-cropping, low soil fertility, landless labours or marginal land holdings, agricultural indebtedness, migration, etc.

\section{Survey and soil sampling}

Fifteen representative villages (Figure 1) were randomly selected from each developmental block of Jhabua and Alirajpur districts for soil sample collection. In each village, six soil samples were collected from the farmers field based on the socioeconomic status particularly on the basis of land holdings (two samples each from marginal and small ( $<2$ ha), medium (2-5 ha) and large ( $>5 \mathrm{ha})$ famers). As these districts comprise of six blocks each, in total 540 geo-referenced surface soil (0-15 $\mathrm{cm}$ depth) samples were collected. In Dhar district, 10 villages from each block were selected and total 780 samples were collected across the 13 blocks in the district (Table 1, Figure 1). The soil sampling was done after harvest of rabi (winter season) crops in the months of March-June during 2013 in Jhabua, during 2014 in Alirajpur, and during 2015 in Dhar, respectively. During soil sampling soil depth was also measured by digging.

\section{Estimation of relative yield}

Yield data was also collected from the farmers during survey and soil sampling and had been used for relative yield calculations. As soil samples were collected from soybean, maize and wheat cultivated fields, equivalent wheat yields (EWY) were calculated for soybean and maize using following formulae:
$\operatorname{EWY}_{\text {Soybean }}\left(\mathrm{kg} \mathrm{ha}^{-1}\right)=\frac{\text { Yield of Soybean }\left(\mathrm{kg} \mathrm{ha}^{-1}\right) \mathrm{X} \text { Price of Soybean }\left(\mathrm{Rs.} \mathrm{kg}^{-1}\right)}{\text { Price of Wheat }\left(\mathrm{Rs} . \mathrm{kg}^{-1}\right)}$

$\operatorname{EWY}_{\text {Maize }}\left(\mathrm{kg} \mathrm{ha}^{-1}\right)=\frac{\text { Yield of Maize }\left(\mathrm{kg} \mathrm{ha}^{-1}\right) \mathrm{X} \text { Price of Maize }\left(\mathrm{Rs.} \mathrm{kg}^{-1}\right)}{\text { Price of Wheat }\left(\mathrm{Rs.} \mathrm{kg}^{-1}\right)}$

The following values were used for calculation that collected from the farmers during survey and sampling and the average prices of produces in the region: soybean- price Rs. $30 \mathrm{~kg}^{-1}$ and yield range was 7.5-18.5 q ha-1; wheat- price Rs. $18 \mathrm{~kg}^{-1}$ and yield range was 19.5-32.0 $\mathrm{q} \mathrm{ha}^{-1}$; and maize- price Rs. $15 \mathrm{~kg}^{-1}$ and yield range was $15.0-26.0 \mathrm{q} \mathrm{ha}^{-1}$.

From the equivalent wheat yield, relative yield was calculated from the following equation as below:

$$
\text { Relative yield }(\%)=\frac{\text { WEYof the location }\left(\mathrm{kgha}^{-1}\right)}{\text { Maximum WEY }\left(\mathrm{kgha}^{-1}\right)} \times 100
$$

\section{Soil analysis}

The collected soil samples were air dried and processed to pass through $2 \mathrm{~mm}$ sieve and analyzed for their physicochemical properties. Silt, and clay content; bulk density (water displacement method); organic carbon; dehydrogenase activity (DHA), $\mathrm{pH}$ and electrical conductivity (1:2.5 soil-water suspension); mineralizable $\mathrm{N}$; available $\mathrm{P}$; available $\mathrm{K}$; available S; DTPA extractable $\mathrm{Zn}, \mathrm{Fe}, \mathrm{Mn}$ and $\mathrm{Cu}$; and hot water soluble B of soils were analysed following standard procedures.

\section{Nutrient index measurement}

Nutrient index (NI) was calculated using the following equation as given by Parker et al. (1951)

Nutrient index $=\left(1 \times N_{1}+2 \times N_{2}+3 \times N_{3}\right) / N$

Where, $\mathrm{N}_{1}=$ Number of soil samples in low category; $\mathrm{N}_{\mathrm{m}}=$ Number of soil samples in medium category; $\mathrm{N}_{\mathrm{h}}=$ Number of soil samples in high category; and $\mathrm{N}=$ Total number of soil samples.

The critical range followed for fixing low, medium and high in all the nutrients were as prescribed in Kundu et al. (2012). The medium ranges were 0.5 $0.75 \%$ for OC, $280-560 \mathrm{~kg} \mathrm{ha}^{-1}$ for $\mathrm{N}, 10-25 \mathrm{~kg} \mathrm{ha}^{-1}$ for P, $120-280 \mathrm{~kg} \mathrm{ha}^{-1}$ for $\mathrm{K}, 10-25 \mathrm{mg} \mathrm{kg}^{-1}$ for $\mathrm{S}$, $0.6-1.2 \mathrm{mg} \mathrm{kg}^{-1} \mathrm{Zn}, 4.5-9.0 \mathrm{mg} \mathrm{kg}^{-1} \mathrm{Fe}, 0.2-0.4 \mathrm{mg}$ $\mathrm{kg}^{-1} \mathrm{Cu}, 2.0-4.0 \mathrm{mg} \mathrm{kg}^{-1} \mathrm{Mn}$, and 1.3-2.6 $\mathrm{mg} \mathrm{kg}^{-1} \mathrm{~B}$. Below and above these ranges, it was considered 


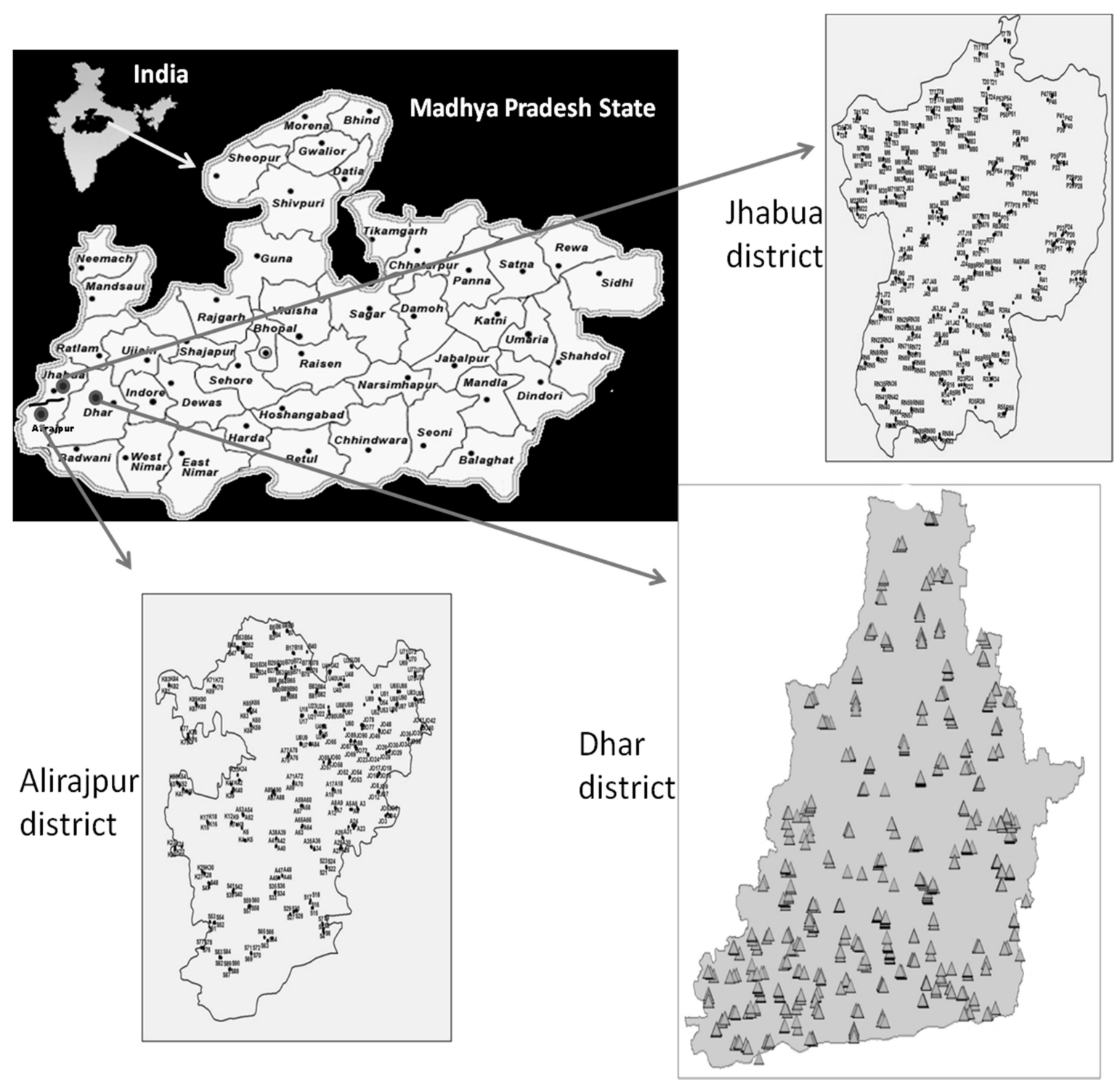

Figure 1: Study area with geo-tagged sampling points in Jhabua, Alirajpur, and Dhar districts.

low and high for respective nutrients. Based on the nutrient index value, the soils are categorized into three classes as follow: NI value less than 1.67 meant for low fertility status; $1.67-2.33$ for medium fertility status; and more than 2.33 is for high fertility status.

\section{Soil quality indicators and a novel scoring procedure}

In the present study, about 15 soil physical, chemical and biological parameters were selected as soil quality indicators based on the expert judgement (Kundu et al., 2012). The score to each indicator was assigned following standard nonlinear scoring procedures (Andrews et al., 2004). For soil depth, soil organic carbon, DHA and available nutrients, "more is better" function is used and the higher scores were assigned to the high values and vice versa (Table 2). In case of silt+clay, bulk density and $\mathrm{pH}$ optimum values are given higher scores and higher and lower values are assigned lower scores as per the expert judgement (Table 2) (Kundu et al., 2012).

Each of the indicator was divided into four classes namely, Class - I, Class - II, Class - III, and Class - IV with an assigned score of 4, 3, 2, and 1, respectively (Table 2) (Kundu et al., 2012). A new method was employed for assigning weight to soil quality indicators in the study. 
Table 1: List of villages surveyed and sampled in each district: Jhabua district $(\mathrm{N}=540)$, Alirajpur district $(\mathrm{N}=540)$ and Dhar district $(\mathrm{N}=\mathbf{7 8 0})(\mathrm{N}=$ Number of soil samples in each district)

\begin{tabular}{|c|c|c|}
\hline District & Block & Villages \\
\hline \multirow{6}{*}{ Jhabua } & Jhabua & $\begin{array}{l}\text { Anthervelia, Gundipada, Bamura Kalyanpur, Basodi, Parvatti, Umari, Semlia bada, } \\
\text { Kardant Badi, Mojipada, Golachoti, Peeplipada, Bhampaliya, Khedi, Nagadia, } \\
\text { Baudibadi }\end{array}$ \\
\hline & Rama & $\begin{array}{l}\text { Mahudipada, Fatepura, Mahuakeda, Para, Edi Choti, Daulat pura, Paledi, Rama, } \\
\text { Mirgarandi, Jamukundi, Sadu, Kheda, Dokerbhani, Kalapan, Kagalco }\end{array}$ \\
\hline & Meghnagar & $\begin{array}{l}\text { Madarani, Chokwada, Mondli, Gwali, Rasodi, Agroll, Rajpura, Chotaguda, Thalawli, } \\
\text { Japadhra, Umaradhara, Peepalkuta, Dedla, PanchPeepliya, Nagarpura }\end{array}$ \\
\hline & Ranapur & $\begin{array}{l}\text { Sothiyajalam, Poochadungri, Retaluniya, Budhasala, Kalapan, Khermal, Junagaun, } \\
\text { Machiliya Jeer, Chuyi, Van, Padalva, Damni Samna, Khadkoyi, Chaparkunda, } \\
\text { Morekundiya }\end{array}$ \\
\hline & Petlawad & $\begin{array}{l}\text { Bherupada, Daturia, Balasa, Pithadi, Amirgadh, Berbet, Saragi, Karwad, Bamnia, } \\
\text { Dulakhedi, Kodali, Rupgadh, Mohancodi, Aisyakhedi, Anathkhedi }\end{array}$ \\
\hline & Tandla & $\begin{array}{l}\text { Semlia (Narela), Kukadipada, Parwada, Khawaza, Sagwa, Baiwasa, Harinaga, } \\
\text { Bhimpuri, Morjhari, Daulatpura, Udaipuria, Kaidels, Bedanta, Kotda(Bheemkunda), } \\
\text { Tandla }\end{array}$ \\
\hline \multirow{6}{*}{ Alirajpur } & Udaigarh & $\begin{array}{l}\text { Sebad, Hardashpur, Temachi, Badaitara, Mota Umar, Dhamantha, Kana Kakad, Baudi } \\
\text { Khurd, Baida, Jeeri choti, Sudi badi, Budagul Badi, Padu Badi, Chuliya, Koliya Barda }\end{array}$ \\
\hline & Alirajpur & $\begin{array}{l}\text { Machaliyapur, Kharkha, Ghatwari, Nanpur, Sejgoan, Ajanta, Somkua, Ali, Indi, Seja, } \\
\text { Nirala, Khotiundva, Burdhan, Ambar, Indersingh Choki }\end{array}$ \\
\hline & Bhabra & $\begin{array}{l}\text { Sejavada, Dugar wani, Amankhuaa, Chotee karati, Babhra, Chote Pol, Badagano, } \\
\text { Mahindra, Barjhar, Emlee Pochi, Mehda, Matana, Gerighati, Khijara, Behdwa }\end{array}$ \\
\hline & Sondwa & $\begin{array}{l}\text { Melgaon, Kulwat, Walpur, Bhurdiya, Sondawa, Ojadu, Ambi, Gundawat, Chakthala, } \\
\text { Puwasa, Umrat, Chotikendra, Bagathgarh, Garajuwara, Mathuwada }\end{array}$ \\
\hline & Kattiwada & $\begin{array}{l}\text { Darkhedi, Sorwa, Kel, Adharkanch, Phulmal, Chandpur, Mordhi, Amba Debry, Palia } \\
\text { Mahu, Amkhoot, Puniawad, Karelimawadi, Bada Kheda, Harodu, Harukheda }\end{array}$ \\
\hline & Jobat & $\begin{array}{l}\text { Salkhera, Khari, Nehtada, Dehdala, Severiya, Padwa, Ranjithgarh, Bilaza, Chhoti } \\
\text { Khattali, Badi Hirapur, Sidhgaon, Kandha, Kalikether, Abgari, Rampura }\end{array}$ \\
\hline \multirow{13}{*}{ Dhar } & Dhar & $\begin{array}{l}\text { Sahalpura, Kesur, Bijur, Nepavli, Jhamurkhedi, Baggedi, Gunavath, Jethpura, Billodh, } \\
\text { Karadiya }\end{array}$ \\
\hline & Nisharpur & $\begin{array}{l}\text { Dahar, Nisarpur, Bhawariya, Susari, Ambada, Lohari, Nimbal, Dahod, Chikalda, } \\
\text { Deshwalia }\end{array}$ \\
\hline & Dahi & $\begin{array}{l}\text { Dahi, Attasuma, Amlal, Badwariya, Phipheda, Arada, Karajwari, Chipwariya, Jamda, } \\
\text { Daram rai }\end{array}$ \\
\hline & Baagh & Padalya, Baagh, Gadvori, Chamjhar, Narwali, Tanda, Badda, Geta, Bhomari, Akada \\
\hline & Gandwani & Avaltha, Jeerabath, Keshvi, Chikliya, Pipli, Gobarva, Gozthana, Kota, Jaamli, Balledi \\
\hline & Manawar & Gulati, Kulvani, Shidhana, Lankur, Bagalya, Jetpur, Eagalwar, Edi, Morat, Devrah \\
\hline & Tirla & $\begin{array}{l}\text { Raipuriya, Chickliya, Damanda, Gumanpura, Sulkanpur, Dilwara, Khedi, Ukala, } \\
\text { Kuva, Kidukiya Kallu }\end{array}$ \\
\hline & Kukshi & $\begin{array}{l}\text { Talanpur, Dolya, Girwaniya, Megra, Awali, Kapsi, Badugyar, Longsari, Umari, } \\
\text { Kundara }\end{array}$ \\
\hline & Umarban & $\begin{array}{l}\text { Pipalma, Kuwat, Lumhera Burjuga, Jheerni, Beerampura, Rawatpura, Ramadhama, } \\
\text { Kalaldha, Peepliya, Banpura }\end{array}$ \\
\hline & Naalcha & $\begin{array}{l}\text { Gumanpura, Karamthalai, Narsinghmal, Sarai, Badikiya, Simsimal, Bhilkhedi, } \\
\text { Bachanpur, Siloda Kurd, Villodha Kurd }\end{array}$ \\
\hline & Badnawar & $\begin{array}{l}\text { Lillikhadi, Bhahatgarh, Kod, Bidwal, Koonone, Nagda, Murrarka, Paikunda, Multhan, } \\
\text { Ghatghara }\end{array}$ \\
\hline & npuri & $\begin{array}{l}\text { Rampura, Mundla, Kakadu dha, Sankota, Mehegoan, Lunerakurd, Gulati, Peepliya } \\
\text { Kurd, Rupatta, Shirsodiya }\end{array}$ \\
\hline & Sardarpur & Ralamandal, Barmandal, Labriy \\
\hline
\end{tabular}


Table 2: Soil quality indicators with their classes and scores for the evaluation of soil quality (Adopted and modified from Kundu et al., 2012)

\begin{tabular}{|c|c|c|c|c|}
\hline Soil quality indicators & Class I & Class II & Class III & Class IV \\
\hline \multicolumn{5}{|l|}{ Physical indicators } \\
\hline Depth (m) & $>2$ & $1-2$ & $0.5-1$ & $<0.5$ \\
\hline Silt+Clay $(\%)$ & $30-40$ & $20-30 / 40-50$ & $10-20 / 50-60$ & $<10 />60$ \\
\hline Bulk density $\left(\mathrm{Mg} \mathrm{m}^{-3}\right)$ & $1.3-1.4$ & $1.3-1.2 / 1.4-1.5$ & $1.2-1.1 / 1.5-1.6$ & $<1.1 />1.6$ \\
\hline \multicolumn{5}{|l|}{ Biological indicators } \\
\hline Organic carbon $(\%)$ & $>1$ & $1-0.75$ & $0.75-0.5$ & $<0.5$ \\
\hline DHA $\left(\mu \mathrm{g}\right.$ TPF $\left.\mathrm{g}^{-1} 24 \mathrm{~h}^{-1}\right)$ & $>20$ & $20-15$ & $15-10$ & $<10$ \\
\hline \multicolumn{5}{|l|}{ Chemical indicators } \\
\hline $\mathrm{pH}$ & $6.5-7.5$ & $6.5-6 / 7.5-8$ & $6-5.5 / 8-8.5$ & $<5.5 />8.5$ \\
\hline Mineralizable $\mathrm{N}\left(\mathrm{kg} \mathrm{ha}^{-1}\right)$ & $>560$ & $560-420$ & $420-280$ & $<280$ \\
\hline Available. $\mathrm{P}\left(\mathrm{kg} \mathrm{ha}^{-1}\right)$ & $>25$ & $15-25$ & $15-10$ & $<10$ \\
\hline Available $\mathrm{K}\left(\mathrm{kg} \mathrm{ha}^{-1}\right)$ & $>280$ & $280-200$ & $200-120$ & $<120$ \\
\hline Available S $\left(\mathrm{mg} \mathrm{kg}^{-1}\right)$ & $>25$ & $25-15$ & $15-10$ & $<10$ \\
\hline DTPA- Zn $\left(\mathrm{mg} \mathrm{kg}^{-1}\right)$ & $>2.0$ & $2.0-1.0$ & $1.0-0.5$ & $<0.5$ \\
\hline DTPA- $\left(\mathrm{mg} \mathrm{kg}^{-1}\right)$ & $>10.0$ & $10-5.5$ & $5.5-2.5$ & $<2.5$ \\
\hline DTPA-Mn (mg kg $\left.{ }^{-1}\right)$ & $>10.0$ & $10.0-4.0$ & $4.0-2.0$ & $<2.0$ \\
\hline DTPA-Cu $\left(\mathrm{mg} \mathrm{kg}^{-1}\right)$ & $>2.0$ & $2.0-0.5$ & $0.5-0.2$ & $<0.2$ \\
\hline Hot water soluble B $\left(\mathrm{mg} \mathrm{kg}^{-1}\right)$ & $>1.5$ & $1.5-0.7$ & $0.7-0.3$ & $<0.3$ \\
\hline Score & 4 & 3 & 2 & 1 \\
\hline
\end{tabular}

Table 3: Criteria for giving weight to different indicators- A new approach

\begin{tabular}{|l|l|l|l|}
\hline Weight & \% distribution of deficiency & Correlation with yield & Co-efficient of variation (\%) \\
\hline 5 & $>80$ & $>0.50$ & $>80$ \\
\hline 4 & $60-80$ & $0.4-0.5$ & $60-80$ \\
\hline 3 & $40-60$ & $0.3-0.4$ & $40-60$ \\
\hline 2 & $20-40$ & $0.2-0.3$ & $20-40$ \\
\hline 1 & $10-20$ & $0.1-0.2$ & $10-20$ \\
\hline 0 & $<10$ & $<0.1$ & $<10$ \\
\hline
\end{tabular}

Weight to each indicator was given based on the following criteria: (1) relation with crop yield (correlation co-efficient), (2) coefficient of variation (extent of variation in a specific region), and (3) percentage distribution of deficiency (Table 3 ). The total weight to each indicator was derived from the sum of weights obtained based on the above three criteria. The final weight of each indicator was considered by converting sum of all the indicators weight to 100 scale range (Table 5).

\section{Soil quality index calculation}

The soil quality index (SQI) was calculated by the following equation given by Wang and Gong (1998).

\section{$\mathbf{S Q I}=\sum\left(\mathbf{W}_{\mathbf{i}} \times \mathbf{I}_{\mathbf{i}}\right)$}

Where, Wi was the weight of the indicator and Ii was the marks/score of the indicator class. Thus, summing up of all the 15 indicators provided the SQI value for a particular soil of the farmer's field. In order to judge the SQI value of any site against the theoretical maximum value of SQI (i.e. 400), the concept of relative soil quality index (RSQI) was used (Singh, 2007). The RSQI was calculated as below:

RSQI $=\frac{S Q I_{\text {sample }}}{S Q I_{\max }} \times 100$

Where, SQI sample was the SQI calculated for particular sample and $\mathrm{SQI}_{\max }$ was the maximum SQI value. Based on the RSQI value, soils of tribal areas were grouped under different categories as described by Singh (2007) (Table 6) and the linear relationship was also established between yield and RSQI following regression statistical model (Figure 2). 


\section{Results and Discussion}

\section{Physicochemical properties of soil}

Most of the soils in the region were sandy loam in texture as $53.7 \%$ and $38.2 \%$ in Alirajpur and Jhabua, respectively; whereas in Dhar, clay $(30.8 \%$ soils) and sandy loam (27.4\%) were the major soil textures. The other soil textures found in the region were sandy clay loam, clay, loam, clay loam and sandy clay (Table 4). Majority of soils are neutral to alkaline $\mathrm{pH}$ with normal electrical conductivity $\left(<1.0 \mathrm{dS} \mathrm{m} \mathrm{m}^{-1}\right)$ (data not included). Soil fertility status of these districts was depicted in Table 4. The nutrient index values ranged for organic carbon (OC), available nutrients $\mathrm{N}, \mathrm{P}, \mathrm{K}, \mathrm{S}, \mathrm{Zn}, \mathrm{Fe}, \mathrm{Cu}$, $\mathrm{Mn}$ and $\mathrm{B}$ were 1.36-1.56, 1.14-1.17, 1.63-1.84, $2.50-2.77,1.23-1.39,2.06-2.17,2.55-2.81,2.92-$ $3.00,2.97-3.00$, and 2.22-2.68, respectively. Based on the nutrient index (NI), the soils of these districts were grouped into low fertility category for $\mathrm{OC}$, available $\mathrm{N}$, and available $\mathrm{S}$. In case of available $\mathrm{P}$, Alirajpur and Jhabua soils had low and Dhar soils had medium fertility status. DTPA extractable- $\mathrm{Zn}$ in the soils of all the three districts was in the medium fertility range. These soils were high in available $\mathrm{K}$, DTPA extractable $\mathrm{Fe}, \mathrm{Cu}$, andMn, and hot water soluble B (Table 4).

The soil quality indicators selected in this study were simple and easily quantifiable parameters Majority of them particularly soil organic carbon, microbial activity, soil depth and available nutrients were used and recommended as important soil quality indicators from the previous studies (Kundu et al., 2012; Srinivasarao et al., 2013; Buennemann et al., 2018; Mahajan et al., 2020). In this study also, soil organic carbon, DHA, available N, S, P and $\mathrm{Zn}$, and soil depth had more weight and affected the soil quality and crop production largely in the region. In this method, it is found that, in Jhabua, SOC was largely influenced the crop yield followed by available N, DHA and available S, P, soil depth and $\mathrm{Zn}$ than soil bulk density, $\mathrm{pH}$, available $\mathrm{K}$ and silt+clay content (Table 5). In Alirajpur, organic carbon and available $\mathrm{P}$ were largely affected the crop yield followed by available S, soil depth, N, DHA, clay+silt, $\mathrm{Zn}$ in the sequence (Table 5). In Dhar, available $\mathrm{N}$ was the most influencing indicator followed by $\mathrm{OC}, \mathrm{Zn}, \mathrm{S}$, $\mathrm{P}$ and soil depth (Table 5). This trend was different from other two districts in the study. The soils in the study area had shallow depth and were prone to erosion because of undulating topography and poor management practices. Major soil texture found in these districts were sandy loam that reported to be poor in water and nutrient holding capacity and conducive to loss of applied fertilizers by leaching process than other textural classes such as loam, clay loam, sandy clay loam, clay, etc. (Hillel, 2003). Further fertility status of the soil was also low particularly in case of OC, N, S, P and Zn. The low soil organic carbon in these soils were because of higher temperatures and poor management practices such as inadequate and imbalanced supply of manures and fertilizers, poor soil and water conservation practices, mono-cropping for a longer period. Similar results were reported by Lal (2004). Inadequate supply of fertilizer nutrients and intensive crop cultivation also led to the deficiency of many numbers of available nutrients in the soils of study area. All the indicators used in the study were not only focused on the production function and also other ecological functions of the soils as addressed in previous studies (Baveye et al., 2016; Buennemann et al., 2018).

\section{Soil quality distribution and crop yield}

The RSQI estimated for the study area by following new approach and soil quality distribution in the study area under different classes/categories were presented in Table 6 . The soil quality of the study area was largely under poor quality category followed by moderately poor and medium category. The soil samples under poor soil quality status were $77.22 \%$ for Jhabua, $85.37 \%$ for Alirajpur, and $67.18 \%$ for Dhar, respectively. In Jhabua, only poor to medium quality soils were found and no good and very good quality soils were found. Among the three districts soil quality was comparatively better in Dhar followed by Jhabua and Alirajpur.However none of the soils in these districts had very good quality (Table 6). The linear regression relationship was established between RSQI and RY in respective districts. They were $\mathrm{RY}=1.66 \times \mathrm{xSQI}-$ $29.3\left(\mathrm{R}^{2}=0.44\right)$ for Jhabua; $\mathrm{RY}=1.34 \mathrm{xRSQI}-12.1$ $\left(\mathrm{R}^{2}=0.48\right)$ for Alirajpur; and $\mathrm{RY}=0.90 \mathrm{xRSQI}+9.67$ $\left(\mathrm{R}^{2}=0.27\right)$ for Dhar, respectively (Figure 2). This showed that there was significant positive correlation exists between RSQI calculated through new approach and the RYs of study area. Further, the soil quality indicators used for deriving SQI 
Table 4:Soil physico-chemical properties and fertility status of the region

\begin{tabular}{|c|c|c|c|c|c|c|c|c|c|c|c|c|c|c|c|}
\hline \multirow[t]{2}{*}{ Texture } & \multicolumn{3}{|c|}{ Percent of soil samples } & \multirow{2}{*}{$\begin{array}{l}\mathrm{pH} \\
\text { (range) }\end{array}$} & \multirow[t]{2}{*}{ Class } & \multicolumn{3}{|c|}{ Percent of soil samples } & \multirow[t]{2}{*}{ Parameters } & \multicolumn{2}{|c|}{ Jhabua } & \multicolumn{2}{|c|}{ Alirajpur } & \multicolumn{2}{|c|}{ Dhar } \\
\hline & Jhabua & Alirajpur & Dhar & & & Jhabua & Alirajpur & Dhar & & NI & Remarks & NI & Remarks & NI & Remarks \\
\hline $\begin{array}{l}\text { Sandy } \\
\text { loam }\end{array}$ & 38.2 & 53.7 & 27.4 & $5.0-6.0$ & $\begin{array}{l}\text { Moderately } \\
\text { acidic }\end{array}$ & 6.67 & 3.89 & 3.21 & $\begin{array}{l}\text { Organic } \\
\text { carbon }\end{array}$ & 1.49 & Low & 1.36 & Low & 1.56 & Low \\
\hline $\begin{array}{l}\text { Sandy } \\
\text { clay } \\
\text { loam }\end{array}$ & 16.4 & 22.2 & 18.6 & $6.0-6.5$ & $\begin{array}{l}\text { Slightly } \\
\text { acidic }\end{array}$ & 13.2 & 6.81 & 6.03 & $\begin{array}{l}\text { Mineralizable- } \\
\mathrm{N}\end{array}$ & 1.14 & Low & 1.14 & Low & 1.17 & Low \\
\hline Clay & 27.2 & 11.6 & 30.8 & $6.5-7.5$ & Neutral & 55.0 & 32.0 & 37.1 & Available P & 1.65 & Low & 1.63 & Low & 1.84 & Medium \\
\hline Loam & 9.11 & 7.2 & 12.4 & $7.5-8.0$ & $\begin{array}{l}\text { Slightly } \\
\text { alkaline }\end{array}$ & 19.1 & 33.4 & 28.7 & Available K & 2.77 & High & 2.50 & High & 2.69 & High \\
\hline $\begin{array}{l}\text { Clay } \\
\text { loam }\end{array}$ & 5.45 & 5.3 & 9.52 & $8.0-8.5$ & $\begin{array}{l}\text { Moderately } \\
\text { alkaline }\end{array}$ & 5.37 & 23.9 & 24.6 & Available S & 1.23 & Low & 1.29 & Low & 1.39 & Low \\
\hline $\begin{array}{l}\text { Sandy } \\
\text { clay }\end{array}$ & 3.64 & - & 1.28 & $>8.5$ & $\begin{array}{l}\text { Highly } \\
\text { alkaline }\end{array}$ & 0.93 & - & 0.36 & DTPA- Zn & 2.17 & Medium & 2.06 & Medium & 2.11 & Medium \\
\hline Total & 100 & 100 & 100 & & Total & 100 & 100 & 100 & DTPA- Mn & 2.99 & High & 2.97 & High & 3.00 & High \\
\hline \multirow{3}{*}{\multicolumn{9}{|c|}{$\begin{array}{l}\text { ND- Not determined } \\
\text { NA- Not applicable } \\
\text { NI-Nutrient Index }\end{array}$}} & DTPA- $\mathrm{Cu}$ & 3.00 & High & 2.93 & High & 2.92 & High \\
\hline & & & & & & & & & DTPA- Fe & 2.81 & High & 2.74 & High & 2.55 & High \\
\hline & & & & & & & & & $\begin{array}{l}\text { Hot water } \\
\text { soluble- B }\end{array}$ & 2.68 & High & 2.22 & Medium & ND & NA \\
\hline
\end{tabular}

Table 5: New approach of giving weight to soil quality indicators for evaluating soil quality

\begin{tabular}{|c|c|c|c|c|c|c|c|c|c|c|c|c|c|c|c|}
\hline \multirow{2}{*}{$\begin{array}{l}\text { Soil quality } \\
\text { indi-cator }\end{array}$} & \multicolumn{5}{|l|}{ Jhabua } & \multicolumn{5}{|l|}{ Alirajpur } & \multicolumn{5}{|l|}{ Dhar } \\
\hline & $\begin{array}{l}\% \text { defici- } \\
\text { ency }\end{array}$ & CV (\%) & $\begin{array}{l}\text { Corre- } \\
\text { lation with } \\
\text { yield }\end{array}$ & $\begin{array}{l}\text { *Wei- } \\
\text { ght }\end{array}$ & $\begin{array}{l}\text { Con- } \\
\text { verted } \\
100 \text { scale }\end{array}$ & $\begin{array}{l}\% \text { defici- } \\
\text { ency }\end{array}$ & CV (\%) & $\begin{array}{l}\text { Corre- } \\
\text { lation with } \\
\text { yield }\end{array}$ & $\begin{array}{l}\text { *Wei- } \\
\text { ght }\end{array}$ & $\begin{array}{l}\text { Con- } \\
\text { verted } \\
100 \text { scale }\end{array}$ & $\begin{array}{l}\% \text { defici- } \\
\text { ency }\end{array}$ & CV (\%) & $\begin{array}{l}\text { Corre- } \\
\text { lation } \\
\text { with yield }\end{array}$ & $\begin{array}{l}\text { *Wei- } \\
\text { ght }\end{array}$ & $\begin{array}{l}\text { Con- } \\
\text { verted } \\
100 \text { scale }\end{array}$ \\
\hline Depth & $80.23(5)$ & 41.3(3) & $0.195(1)$ & 9 & 8.82 & $84.05(5)$ & $34.28(2)$ & $0.445(4)$ & 11 & 10.2 & $56.71(3)$ & $41.3(3)$ & $0.22(2)$ & 8 & 8.33 \\
\hline Silt+Clay & $68.84(4)$ & $31.11(2)$ & $0.088(0)$ & 6 & 5.87 & $78.90(4)$ & $15.24(1)$ & $0.232(2)$ & 7 & 6.48 & $42.21(3)$ & $26.31(2)$ & $0.18(1)$ & 6 & 6.25 \\
\hline $\mathrm{BD}$ & $20.42(2)$ & $3.67(0)$ & $0.041(0)$ & 2 & 1.96 & $34.91(2)$ & $8.24(0)$ & $0.125(1)$ & 3 & 2.78 & $23.59(2)$ & $7.06(0)$ & $0.14(1)$ & 3 & 3.13 \\
\hline $\mathrm{OC}$ & $88.60(5)$ & $36.02(2)$ & $0.552(5)$ & 12 & 11.8 & $91.94(5)$ & $36.55(2)$ & $0.537(5)$ & 12 & 11.1 & $87.43(5)$ & $33.69(2)$ & $0.38(3)$ & 10 & 10.4 \\
\hline DHA & $65.42(4)$ & $21.32(2)$ & $0.412(4)$ & 10 & 9.80 & $65.15(4)$ & $19.12(1)$ & $0.429(4)$ & 9 & 8.33 & $65.42(4)$ & $24.64(2)$ & $0.27(2)$ & 8 & 8.33 \\
\hline $\mathrm{pH}$ & $12.42(1)$ & $9.63(0)$ & $0.075(0)$ & 1 & 0.98 & $17.18(1)$ & $11.57(1)$ & $0.182(1)$ & 3 & 2.78 & $28.08(2)$ & $8.88(0)$ & $0.28(2)$ & 4 & 4.16 \\
\hline $\mathrm{N}$ & $100.0(5)$ & $23.52(2)$ & $0.459(4)$ & 11 & 10.8 & $99.43(5)$ & $33.32(2)$ & $0.345(3)$ & 10 & 9.26 & $100(5)$ & $44.85(3)$ & $0.37(3)$ & 11 & 11.5 \\
\hline $\mathrm{P}$ & $58.7(3)$ & $65.14(4)$ & $0.294(2)$ & 9 & 8.82 & $61.20(4)$ & 66.22(4) & $0.461(4)$ & 12 & 11.1 & $62.43(4)$ & $52.54(3)$ & $0.16(1)$ & 8 & 8.33 \\
\hline $\mathrm{K}$ & $12.12(1)$ & $24.32(2)$ & $0.083(0)$ & 3 & 2.95 & $22.87(2)$ & $38.96(2)$ & $0.170(1)$ & 5 & 4.63 & $10.77(1)$ & $34.43(2)$ & $0.10(1)$ & 4 & 4.16 \\
\hline $\mathrm{S}$ & $91.25(5)$ & $34.17(2)$ & $0.356(3)$ & 10 & 9.80 & $86.3(5)$ & $49.80(3)$ & $0.396(3)$ & 11 & 10.2 & $84.10(5)$ & $57.72(3)$ & $0.14(1)$ & 9 & 9.38 \\
\hline $\mathrm{Zn}$ & $45.70(3)$ & $32.06(2)$ & $0.317(3)$ & 8 & 7.85 & $37.86(2)$ & $77.88(4)$ & $0.178(1)$ & 7 & 6.48 & $57.05(3)$ & 79.02(4) & $0.29(2)$ & 10 & 10.4 \\
\hline $\mathrm{Fe}$ & $5.27(0)$ & $57.21(3)$ & $0.205(2)$ & 5 & 4.89 & $5.70(0)$ & $55.79(3)$ & $0.013(0)$ & 3 & 2.78 & $10.38(1)$ & $59.49(3)$ & $0.19(1)$ & 5 & 5.21 \\
\hline $\mathrm{Mn}$ & $1.30(0)$ & $53.68(3)$ & $0.118(1)$ & 4 & 3.92 & $3.1(0)$ & $66.90(4)$ & $0.045(0)$ & 4 & 3.70 & $0(0)$ & $60.65(4)$ & $0.16(1)$ & 3 & 3.13 \\
\hline $\mathrm{Cu}$ & $8.92(0)$ & $87.63(5)$ & $0.101(1)$ & 6 & 5.87 & $6.7(0)$ & $86.38(5)$ & $0.027(0)$ & 5 & 4.63 & $6.41(0)$ & $98.05(5)$ & $0.21(2)$ & 7 & 7.29 \\
\hline B & $26.8(2)$ & $32.10(2)$ & $0.272(2)$ & 6 & 5.87 & $44.2(3)$ & $50.21(3)$ & $0.024(0)$ & 6 & 5.55 & - & - & - & - & - \\
\hline Total & - & - & - & 102 & 100 & - & - & - & 108 & 100 & - & - & - & 96 & 100 \\
\hline
\end{tabular}

Note: value in the parenthesis is weight under each criterion; *weight of each indicator obtained by sum of weights under all three criteri 
adopting new approach were accounted only $44 \%$, $48 \%$, and $27 \%$ of production functions in Jhabua, Alirajpur and Dhar, respectively. Soil quality of the tribal area of central India was found to be poor. None of the soils in the region had very good quality. The poor soil fertility and soil quality of the study area might be due low soil organic carbon, inappropriate land use and soil management, excessive nutrient mining, deficiency of available nutrients, soil erosion, poor microbial activity, etc. (Velayutham et al., 1999). The similar results of soil quality degradation in other parts of India had been described by many workers (Srinivasarao et al., 2013; Mahajan et al., 2020). Further there was a high positive relationship existed between SQIs calculated adopting new method and RYs. The new approach adopted for SQI calculation was highly suitable and reflected the actual status of soil quality and crop productivity of study area. Soil factors that largely influenced the crop productivity in the region are organic carbon, available $\mathrm{N}, \mathrm{S}, \mathrm{P}$, Zn, dehydogenase activity (DHA) and soil depth. Similar results of influence of organic matter, microbial acitivities and available nutrients on crop yield were reported by other researchers (Masto et al., 2008, Kundu et al., 2012; Vasu et al., 2017; Mahajan et al., 2020). Moreover, the SQI calculated had accounted $27-48 \%$ of productivity functions in the region (Figure 2). This showed that the other factors apart from the soil quality indicators used in the study influenced the crop production functions. They could be climate, topography, rainfall pattern, water availability, cultivars used, pest and diseases, etc. (Nayak et al., 2019). These were beyond the scope of the current investigation.
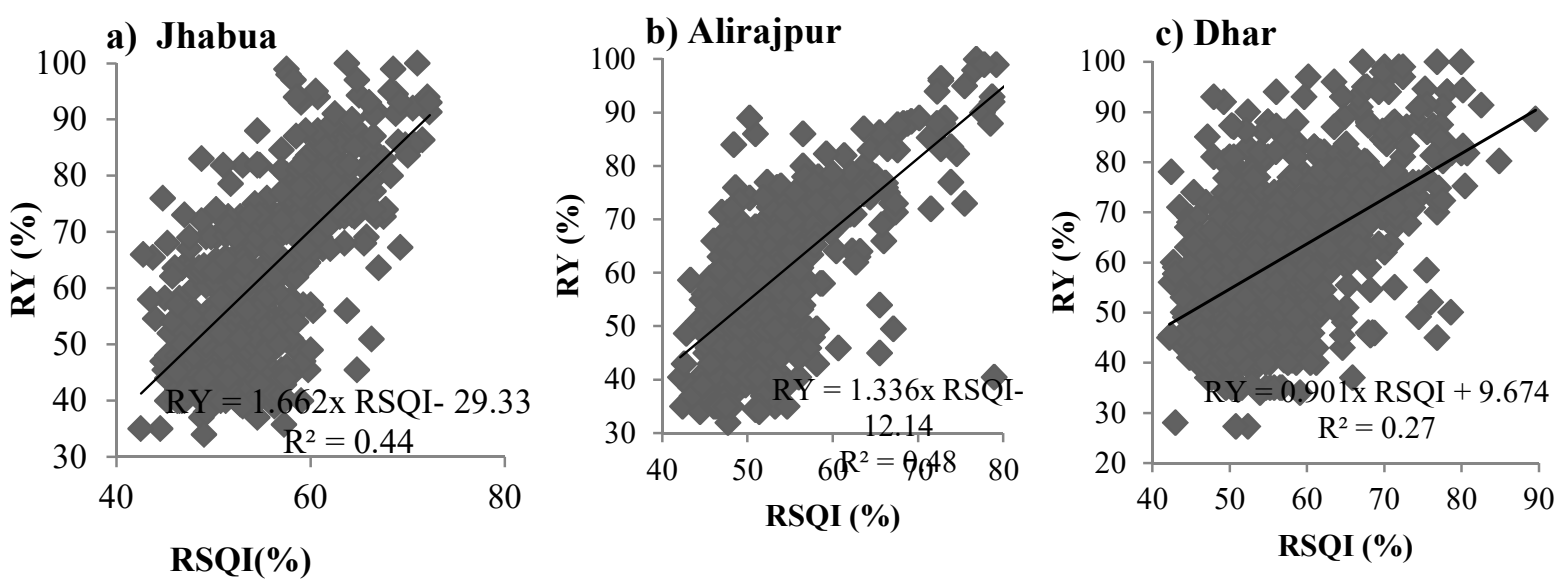

Figure 2: Interrelationship between relative soil quality index (RSQI) and relative yield (RY) in a) Jhabua; b) Alirajpur; and c) Dhar districts

Table 6: Classes/Category of soil quality based on relative soil quality index (RSQI) and soil quality status of study area (Adopted from Singh, 2007)

\begin{tabular}{|l|l|l|l|l|l|}
\hline $\begin{array}{l}\text { RSQI } \\
(\%)\end{array}$ & Classes & Category & $\begin{array}{l}\text { Jhabua } \\
\text { (\% distribution) }\end{array}$ & $\begin{array}{l}\text { Alirajpur } \\
\text { (\% distribution) }\end{array}$ & $\begin{array}{l}\text { Dhar } \\
\text { (\% distribution) }\end{array}$ \\
\hline$>90$ & I & Very Good & Nil & Nil & Nil \\
\hline $80-90$ & II & Good & Nil & 0.19 & 0.90 \\
\hline $70-80$ & III & Medium & 1.48 & 4.44 & 9.23 \\
\hline $60-70$ & IV & Moderately Poor & 21.30 & 10.00 & 22.69 \\
\hline$<60$ & V & Poor & 77.22 & 85.37 & 67.18 \\
\hline
\end{tabular}




\section{Significance of new approach of soil quality assessment}

Soil quality assessment through the new approach reflected the actual status of soil in the study area. For example, in Alirajpur and Jhabua district, the percentage of poor quality soils was $85.37 \%$ and $77.22 \%$; whereas in Dhar district, the percenaget of poor quality soils were $67.18 \%$. This reflected in the average crop productivity of the districts. The mean crop productivity of Dhar district was higher than that of Jhabua district. Moreover, the new approach was more accurate and systematic. Weight to each indicator was given on the basis of its relation with crop yield, variation and high percent of deficiency/lower class. In previous studies, expert judgement and statistical technique (Principal component analysis, PCA) were mainly used for indexing soil quality (Singh 2007, Kundu et al., 2012; Vasu et al., 2017; Mahajan etal., 2020). However the SQI values varied for different methods for same field conditions reported by the same authors (Andrews et al., 2004). Further, Vasu et al. (2017) had demonstrated that expert opinion method was better than PCA method in relation to production functions. Simply depending on statistical techniques based on the generated data might not reflect the actual picture of the field conditions, therefore experts intervention required to judge or select the soil quality indicators. Expert opinion method though well reflected the production functions of study area, might not give much attention towards other ecological functions (Baveye et al., 2016; Bounnemann et al., 2018; Nayak et al., 2019). In the new approach, the method employed not only focus on production function; it was inclusive of other ecological

\section{References}

Andrews,S.S., Karlen,D.L., \&Cambardella,C.A.(2004). The soil management assessment framework: A quantitative soil quality evaluation method. Soil ScienceSociety America Journal,68:1945-1962.

Baveye,P.C., Baveye,J.,\&Gowdy, J. (2016)). Soil "ecosystem” services and natural capital: critical appraisal of research on uncertain ground. Frontiers in Environmental Science, $4: 1-49$.

Brussaard,L.(2012).Ecosystem services provided by the soil biota. In. D.H.Wall, R.D.Bardgett, V.Behan-Pelletier, J.E.Herrick, H.Jones, K.Ritz, J.Six, D.R.Strong, \&W.H. functions of soil. For example, equal preferences/weight was given to percent variation and deficiency of soil parameters in the region apart from crop yield relationship. Also it focused soil threats in the area for selecting suitable land use and soil use management to sustain major ecological functions of soil (Brussaard, 2012). In total the new approach was very simple; systematic; principally management oriented; focused on soil threats; gave equal importance to major ecological services of soils.

\section{Conclusion}

To sum up, most of the soils in the region are deficient in soil organic carbon and many mineral nutrients. Moreover the new approach of soil quality indexing has revealed that soil qualities in the study area are poor and highly degraded. The major soil threats in the region are decline soil organic matter, soil erosion, chemical degradation (nutrient deficiency and mining), loss of biodiversity, etc. which affect the various soil functions or processes and soil based ecosystem services. The novel soil quality assessment approach is very simple and systematic than other approaches such as statistical models. The principle can be further adopted in other regions for the similar purposes. This approach is principally management related and focuses mainly on soil parameters that constraint production and ecological functions. Practicing sustainable land use and soil management to alleviate the identified soil constraints can improve soil quality, crop productivity and other soil ecological services in the region.

van der Putten (eds.), Soil Ecology and Ecosystem Services, Oxford University Press, Oxford, UK., pp: 45-58.

Bunemann,E.K., Bongiorno,G., Bai,Z., Creamer,R.E., De Deyn,G., De Goede,R., Fleskens,L., Geissen,V., Kuyper,T.W., Mader,P., Pulleman,M., Sukkel,W., Groenigen,J.W.V., \&Brussaard, L.(2018). Soil quality - A critical review. Soil Biology and Biochemisstry, 120:105125.

Hillel,D.(2003).Introduction to Environmental Soil Physics, first ed. Academic Press, London. 
Kundu,S., Vassanda Coumar,M., Saha,J.K., Rajendiran,S., Hati,K.M., Biswas,A.K., Reddy,K. S., \&Subba Rao,A.(2012). Assessing soil health of vertisol of AESR10.1 using selected physical, chemical and biological attributes of soils. Journal of the Indian Society of Soil Science, 60:281-287.

Lal,R.(2004). Soil carbon sequestration impacts on global climate change and food security. Science, 304:162311627.

Mahajan,G., Das,B., Morajkar,S., Desai,A., Murgaokar,D., Kulkarni,R., Sale,R., \& Patel,K. (2020). Soil quality assessment of coastal salt-affected acid soils of India.Environment Science and Pollution Research,27:26221-26238.

Masto,R.E., Chhonkar,P.K., Singh,D., \&Patra, A.K (2008).Alternative soil quality indices for evaluating the effect of intensive cropping, fertilisation and manuring for 31 years in the semi-arid soils of India. Environmental Monitoring and Assessment, 136:419-435.

NAAS. (2017).Mitigating Land Degradation due to Water Erosion. Policy Paper No. 88 National Academy of Agricultural Sciences, New Delhi.

NAAS. (2012).Sustaining Agricultural Productivity through IntegratedSoil Management. Policy Paper No. 56, National Academy ofAgricultural Sciences, New Delhi.

NAAS. (2006).Low and Declining Crop Response to Fertilizers. Policy Paper No. 35, National Academy of Agricultural Sciences, New Delhi.

Nayak ,A.K., Shahid,M., Nayak,A.D.,Dhal,B., Moharana,K.C., Mondal,B., Tripathi,R., Mohapatra,S.D., Bhattacharyya,P.,
Jambhulkar, N.N., Shukla, A.K., Fitton ,N., Smith, P., \&Pathak,H. (2019). Assessment of ecosystem services of rice farms in eastern India. Ecological Processes, 8:35-50.

Parker,F.W., Nelson,W.L., Eric,W., \&Miller,I.E. (1951). The broad interpretation of soil test information. Agronomy Journal, 43:105-102.

Shukla,A. K., \&Behera,S.K.(2012).Micronutrient fertilizers and higher productivity. Indian Journal of Fertilisers, $8: 100-117$

Singh,A.K. (2007). Evaluation of soil quality under integrated nutrient management. Journal of the Indian Society of Soil Science, 55:58-61.

Srinivasarao,CH., Venkateswarlu,B., Lal,R., Singh, A.K., \& Kundu,S. (2013). Sustainable management of soils of dryland ecosystems of India for enhancing agronomic productivity and sequestering carbon. Advances in Agronomy, 121:253-329.

Vasu,D., Singh,S.K., Ray,S.K., Duraisami,V.P., Tiwary,P., Chandran,P., Nimkar, A.M.\&Anantwar,S.G.(2016).Soil quality index (SQI) as a tool to evaluate crop productivity in semi-arid Deccan plateau, India. Geoderma,282:70-79.

Velayutham, M., Mandal, D.K.,Mandal C., \& Sehgal, J. (1999). Agro-Ecological Sub-Regions of India for Planning and Development. ICAR-National Bureau of Soil Survey and Land Use Planning, Nagpur.

Wang, X.J. \&Gong, Z.T. (1998). Assessment and analysis of soil quality changes after eleven years of reclamation in subtropical China. Geoderma,81:339-355. 